\title{
Acetylcholinesterase Activity in Fish Exposed to Mercury in Guanabara Bay, RJ, Brazil
}

Ana Paula de Castro Rodrigues ${ }^{1 *}$; Rodrigo Guerra Carvalheira ${ }^{1}$; Vanessa Gomes ${ }^{2}$; Ana Rosa Linde Arias ${ }^{2}$; Nádia Regina Pereira Almosny ${ }^{3}$ Z Zuleica Carmen Castilhos $^{4}$; Edison Dausacker Bidone ${ }^{1}$

${ }^{1}$ Geochemistry Department, Fluminense Federal University, Niterói, Brazil

${ }^{2}$ CESTEH, Osvaldo Cruz Foundation, Rio de Janeiro, Brazil

${ }^{3}$ Veterinary School, Fluminense Federal University, Niterói, Brazil

${ }^{4}$ Centre for Mineral Technology, Rio de Janeiro, Brazil

E-mail: tantufaz17@gmail.com

\begin{abstract}
Acetylcholinesterase (AChE) is an important regulatory enzyme that controls the transmission of nerve impulses across cholinergic synapses. This study evaluated AChE activity as an effect biomarker for ecological risk assessment related to mercury contamination in fish from Guanabara bay, Rio de Janeiro State, Brazil. A total of 30 fishes were collected, 14 specimens of Genidens genidens and 16 specimens of Haemulon sp. at three sampling stations. AChE activity

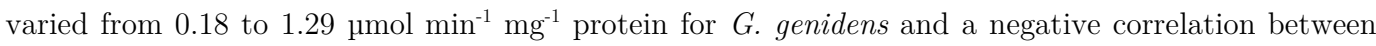
AChE activity in muscles and mercury concentrations in kidney was found $(-0.55 ; \mathrm{p}<0.05 ; \mathrm{n}=14)$. For Haemulon sp. the enzyme activity showed a smaller range (0.06 to $\left.0.22 \mu \mathrm{mol} \mathrm{min} \mathrm{mg}^{-1} \mathrm{mg}^{-1} \mathrm{protein}\right)$ and a negative correlation between mercury concentrations in muscles and AChE activity was found $(\mathrm{r}=-0.570 ; \mathrm{p}<0.05 ; \mathrm{n}=16)$, suggesting a decrease on enzymatic response in specimens with higher mercury bioaccumulation.
\end{abstract}

Keywords: Biomarkers, cholinesterases, Genidens genidens, Haemulon sp., metals.

\section{Introduction}

Acetylcholinesterase (AChE) is an enzyme that hydrolyzes acetylcholine molecules and it is an important regulatory enzyme that controls the transmission of nerve impulses across cholinergic synapses. Its inhibition in fish has been commonly linked to organophosphorades, carbamates and other pesticides exposure [1], [2], [3], [4] and it has resulted in an excess of stimulus on cholinergic nerves, causing alterations on swimming, tremors and convulsion [4]. Besides organic pollutants, some authors indicate also the possibility of inhibition in cases of exposure to cooper [5], [6], [7], [8], [9], [10], [11], [12], [13], cadmium [12], [14], arsenium [15] and lead [12].

Now for mercury exposure, despite its high toxicity, the inhibition process is not well understood, especially when fish exposure is to the most common organic mercury form (methylmercury - MeHg), a neurotoxic and teratogenic substance [16]. Mercury $(\mathrm{Hg})$ is considered as one of the most toxic metals by the World Health Organization [17]. Some studies observed AChE inhibition due to mercury exposure [10], [12], [13], [18], [19], [20], [21], [22]. Jesus et al. [23], [24], when considering neotropical fish species, evaluated possible effects on acetylcholinesterase activity and internal distribution of mercury in a carnivorous species (Hoplias malabaricus), using intraperitonial injections of mercury and methylmercury chlorides. Costa et al. [25] observed an inhibition of this enzyme on Hoplias malabaricus, using a methylmercury exposure dose of $75 \mathrm{ng} \mathrm{g}^{-1}$, in laboratory conditions, after 70 days of exposure to this contaminant by contaminated food ingestion (the preys were artificially contaminated with intraperitoneal injections).

At Rio de Janeiro State (Brazil), mercury contamination is observed in sediments from the northwest region of Guanabara bay, which is one of the largest bays of Brazil and has the metropolitan area of Rio de Janeiro State on its drainage basin. Machado et al. [26] found an important gradient of mercury concentrations in superficial sediments, being the lowest concentration found at a protection area, with 
mangroves, at the Guapimirim River estuary (61.0 $\left.\mathrm{ng} \mathrm{\textrm {g } ^ { - 1 }}\right)$ and the maximum concentration was described for Meriti River estuary $\left(7,500 \mathrm{ng} \mathrm{g}^{-1}\right)$, which has a chlor-alcali plant on the drainage basin. Low mercury concentrations in fish species have been reported [27], [28], however, risks to these animals health were already pointed out [21]. Therefore, the main objective of this study is to evaluate AChE activity as an effect biomarker for the ecological risk assessment related to mercury contamination in fish from Guanabara bay, Rio de Janeiro State, Brazil.

\section{$2 \quad$ Material and Methods}

For this study two demersal fish species were chosen. The first species was a catfish (Genidens genidens), from Ariidae Family, with high economical relevance. It is well distributed, with high frequencies in estuarine environments. Its maximum length is $35 \mathrm{~cm}$ [29]. It is not a restricted carnivorous species, feeding on benthic organisms, such as algae, superior plants, crustaceans (Decapode, Amphipoda, Copepods, Isopods), mollusks (bivalves and gastropods), Polychaeta (Nereidae and Glyceridae) and other fishes [30]. Also ingests a high percentage of sediments, being probably more exposed to mercury contamination than pelagic species.

The second species is from the Haemulon genus, from Perciformes Order, Haemulidae Family. This species is able to live at different habitats, including bays, beaches and estuaries, with rocky, coralline or sandy substrates, near the shoreline. The juveniles feed mainly on zooplankton and the adults, on benthic invertebrates, fishes and algae [29]. It is commonly called as grunt. It has low economic value, but it is commonly catched in Guanabara bay.

Sampling was carried out using bottom doors trawl, at $5 \mathrm{~m}$ of depth, during 30 minutes, between March 2008 and August 2009, at three sampling stations (Figure 1): station 1 - Bica Beach $\left(22^{\circ} 49^{\prime} 7.71^{\prime \prime} \mathrm{S} ; 43^{\circ} 11^{\prime} 8.24^{\prime \prime} \mathrm{W}\right)$, near to Governador Island; station 2 - Gradim $\left(22^{\circ} 49^{\prime} 5.33^{\prime \prime} \mathrm{S} ; 43^{\circ}\right.$

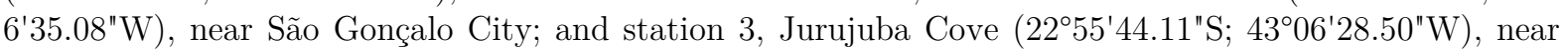
to the bay's mouth.

A total of 30 fishes were collected, 14 specimens of Genidens genidens and 16 specimens of Haemulon sp. G. genidens were from stations 1 and 3 , mainly station 3 (9 specimens). $H$. sp. specimens were from station 4, exclusively. Axial muscles samples were obtained following the methodology suggested by Standard Methods. Kidney samples were collected after dissection of the ventral cavity from the anus to the mouth [32]. Total and standard lengths were measured in laboratory and are expressed in $\mathrm{cm}$.

Wet samples of muscles and kidneys were homogenized and the determinations were performed in triplicates. For each replicate, around $0.03 \mathrm{~g}$ of tissue was used. Total mercury was measured using a portable atomic absorption (LUMEX), specific for total mercury analysis by spectrophotometer. For this methodology, the samples were only homogenized. None previous treatment was necessary, since this equipment worked with pyrolysis, where the samples were submitted to high temperatures (above $800^{\circ} \mathrm{C}$ ) in a pyrolysis chamber, volatilizing mercury (all chemical forms) for its detection. The results are expressed as wet weight. For accuracy evaluation, certified material (IEAE 407, mercury concentration $=222 \mathrm{ng} \mathrm{g}^{-1}$ ) analysis was performed every day, with an acceptable error of $10 \%$ (maximum). The detection limit was $5 \mathrm{ng} \mathrm{g}^{-1}$. The mean value found for the certified material was $218.4 \pm 14.3 \mathrm{ng} \mathrm{g}^{-1}(\mathrm{n}=5)$, resulting in an error of $1.8 \%$.

The determinations of the AChE activity in fish muscles followed the method described by Oliveira Silva et al. [33], with modifications, whose quantifications were based on the reaction described by Ellman et al. [34]. Small portions of muscle samples were weighted and homogenized in sodium phosphate $0.12 \mathrm{M}$, pH 7.6 (6:1). The samples were centrifuged $\left(9,000 \mathrm{G} ; 20\right.$ minutes; $\left.8^{\circ} \mathrm{C}\right)$. While the samples were centrifuging, test tubes were prepared containing $2 \mathrm{~mL}$ of sodium phosphate and $0.5 \mathrm{~mL}$ of DTNB $2 \mathrm{mM}$. At the time of lecture, $500 \mu \mathrm{L}$ of acetylcholine and $25 \mu \mathrm{L}$ of sample were added into those previously prepared tubes. Enzymatic activities were determined in spectrophotometer in kinetic form $(\lambda$ $=412 \mathrm{~nm}$ ), being obtained after two minutes of reaction, the absorbance per minute. For protein determination, muscles samples were diluted (1:10) in sodium phosphate solution $0.12 \mathrm{M} \mathrm{pH} 7.6$. In test tubes were added $4.3 \mathrm{~mL}$ of distilled $\mathrm{H}_{2} \mathrm{O}, 200 \mu \mathrm{L}$ of $\mathrm{NaOH} 25 \%$ and $200 \mu \mathrm{L}$ of diluted sample. The blank contained $4.5 \mathrm{~mL}$ of $\mathrm{H}_{2} \mathrm{O}$ distilled and $200 \mu \mathrm{L}$ of $\mathrm{NaOH} 25 \%$. In the first tube (blank) $300 \mu \mathrm{L}$ of Folin reagent was added, and homogenized on a vortex during 30 seconds. The same process of homogenization was made to all tubes. After 5 minutes, the absorbance was measured in photometric 
model, in a spectrophotometer Shimadzu UV $1601(\lambda=660 \mathrm{~nm})$. The absorbance was converted to protein concentration $\left(\mathrm{mg} \mathrm{mL} \mathrm{m}^{-1}\right)$ using an albumin curve. The specific activity of $\mathrm{AChE}\left(\mu \mathrm{mol} \mathrm{min}^{-1} \mathrm{mg}^{-1}\right.$ protein) was obtained by ratio of the enzyme activity and the protein concentration [35].

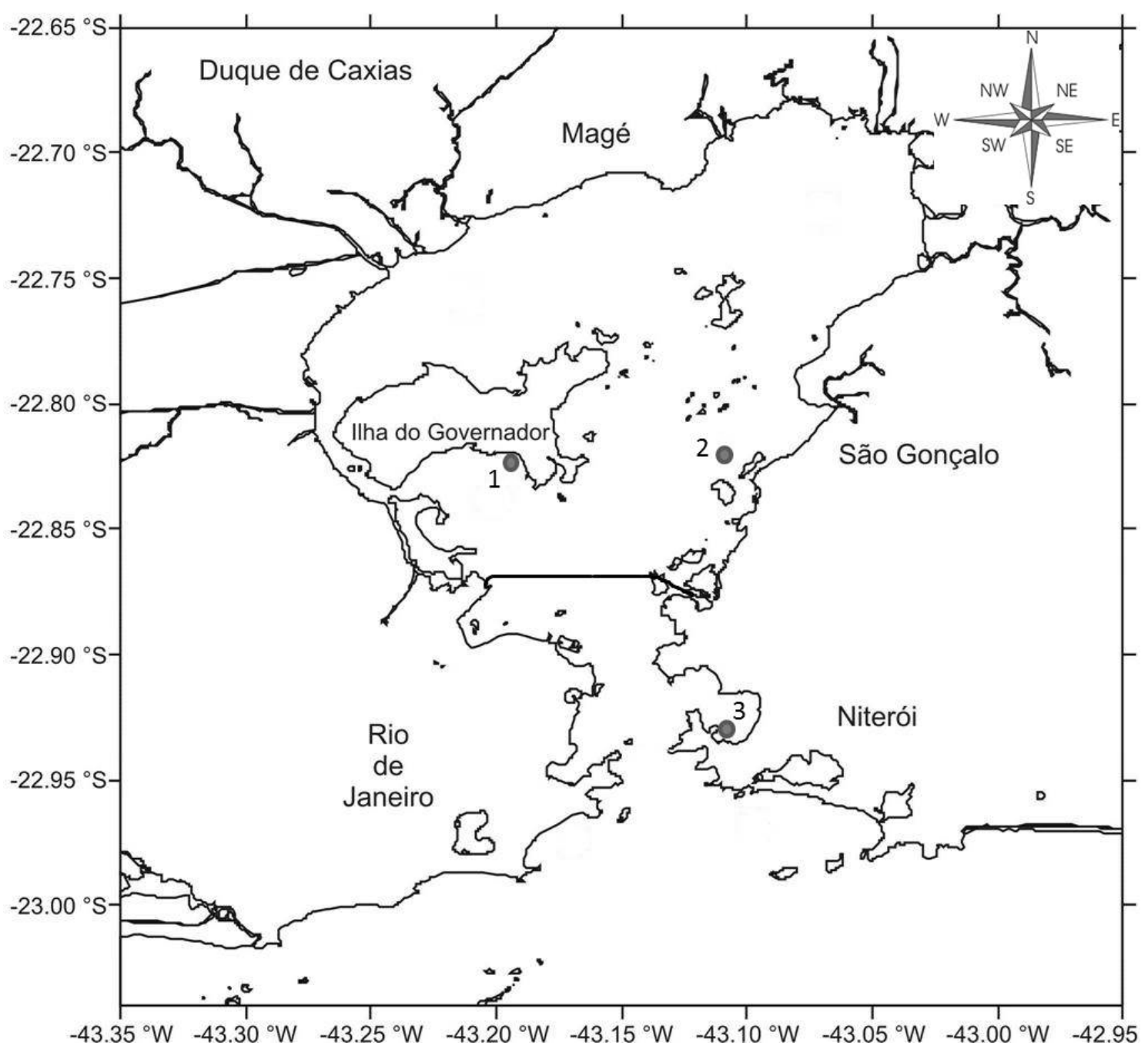

Figure 1. Study area (Guanabara bay, Rio de Janeiro State, Brazil) and localization of fish sampling stations (1, 2 and 3$)$.

Statistical treatment was performed using the software SPSS 18.0, being investigated possible correlations between mercury concentrations and AChE activity, applying the Spearman correlation coefficient. Also the differences between species were investigated using a non-parametric test (MannWhitney $U$ Test). In order to compare the present results with previous works of our group, a parametric hypothesis test (T Student test) was applied. All tests considered the significance level of $\mathrm{p}<0.05$. Additionally, linear regressions between mercury concentrations and AChE activity for both fish species were performed using Excel 2010 (Office Package 2010).

\section{$3 \quad$ Results and Discussion}

The results organized by each sampling station are shown in Table 1 . AChE activity varied from 0.18 to $1.29 \mu \mathrm{mol} \mathrm{min} \mathrm{mg}^{-1}$ protein for Genidens genidens. Azevedo et al. [36] evaluated the basis activity of AChE for another catfish Cathorops spixii (Agassiz, 1829), from the same taxonomic Family of $G$. 
genidens, using available published data from Brazil. The AChE activity in muscles proposed by those authors for uncontaminated areas was $0.055 \pm 0.005 \mu \mathrm{mol} \mathrm{min}^{-1} \mathrm{mg}^{-1}$ protein, using Paranaguá bay as reference area. For contaminated areas, the suggested activity was $0.086 \pm 0.008 \mu \mathrm{mol} \mathrm{min}^{-1} \mathrm{mg}^{-1} \mathrm{protein}^{-1}$ for Paranaguá bay and between 0.062-0.068 $\mu \mathrm{mol} \mathrm{min}^{-1} \mathrm{mg}^{-1}$ protein for Santos-São Vicente bay. All suggested activities were quite different from those found in the present work for a taxonomic related species. Oliveira et al. [38] described an AChE activity of $376 \mathrm{U} \mathrm{g}^{-1}$ in brain, of $28 \mathrm{~cm}$ specimens of $G$. genidens, on Brazilian coastal area.

Table 1. Average \pm standard deviation of total mercury concentrations (wet weight; ng $^{-1}$ ) in muscles (HgM) and in kidney $(\mathrm{HgK})$, acetylcholinesterase activity $(\mathrm{AChE})$ in muscles ( $\mathrm{mmol} \mathrm{min} \mathrm{mg}^{-1}$ protein) and total (TL) and standard (SL) length $(\mathrm{cm})$ of two fish species from Guanabara bay, Brazil. $(\mathrm{n})=$ number of specimens.

\begin{tabular}{|c|c|c|c|}
\hline Parameters & $\begin{array}{l}\text { Station \#1 } \\
\text { Bica Beach }\end{array}$ & $\begin{array}{c}\text { Station \#2 } \\
\text { Gradim }\end{array}$ & $\begin{array}{c}\text { Station \#3 } \\
\text { Jurujuba Cove }\end{array}$ \\
\hline \multicolumn{4}{|c|}{ Genidens genidens } \\
\hline TL & $20.5 \pm 3.5(2)$ & $18.3 \pm 3.0(9)$ & * \\
\hline $\mathrm{SL}$ & $16.7 \pm 3.2(2)$ & $15.1 \pm 2.4(9)$ & $*$ \\
\hline $\mathrm{AChE}$ & $0.484 \pm 0.252(2)$ & $0.611 \pm 0.311(9)$ & * \\
\hline $\mathrm{HgM}$ & $170.3 \pm 32.4(2)$ & $67.2 \pm 61.5(9)$ & * \\
\hline $\mathrm{HgK}$ & $153.5 \pm 7.8(2)$ & $78.9 \pm 78.2(9)$ & $*$ \\
\hline \multicolumn{4}{|c|}{ Haemulon sp. } \\
\hline TL & $*$ & $* *$ & $14.4 \pm 2.7(16)$ \\
\hline $\mathrm{SL}$ & $*$ & $* *$ & $11.7 \pm 2.2(16)$ \\
\hline $\mathrm{AChE}$ & * & $* *$ & $0.151 \pm 0.052(16)$ \\
\hline $\mathrm{HgM}$ & $*$ & $* *$ & $64.7 \pm 63.4(16)$ \\
\hline $\mathrm{HgK}$ & $*$ & $* *$ & $\#$ \\
\hline
\end{tabular}

* The specimens collected at this station were not included on the evaluation due to losses of frozen material before AChE analysis.

** There was no capture of this species at Station 2.

\# This species has a very small kidney and it was not possible to perform mercury determinations.

The AChE activity observed for G. genidens agrees with previous published data [21], where 39 specimens of this species from Guanabara bay showed an average of $0.91 \pm 0.41 \mu \mathrm{mol} \mathrm{min}^{-1} \mathrm{mg}^{-1} \mathrm{protein}^{-1}$ and 33 specimens from Ribeira bay (reference area) showed an average of $0.79 \pm 0.54 \mu \mathrm{mol} \mathrm{min}^{-1} \mathrm{mg}^{-1}$ protein. The AChE activity found in the present work was 1.5 times lower than the described in Rodrigues et al [21], being significantly different ( $\mathrm{T}$ Student test; t-value: -2.24 ; $\mathrm{p}<0.05$ ), but mercury concentrations were similar ( $\mathrm{T}$ Student test; t-value: -1.68; $\mathrm{p}=0.099$ ) (Figure 2). Even with similar mercury concentrations, G. genidens answered in a different way for AChE in comparison with this previous work. This could be associated to environmental variations that influences on biochemical responses.

One possible explanation is seasonality of AChE activities, influenced by both season (Spring $\mathrm{x}$ Summer) and year (4 years separated the previous study from the present data). Another important point is the sampling stations; in the previous work, specimens were collected exclusively at station 1. Both stations 1 and 2 receive untreated domestic wastes, and have short water column depth and nowadays, station 2 is being used as final destination deposition area for sediments from dredging activities at Guanabara bay. 

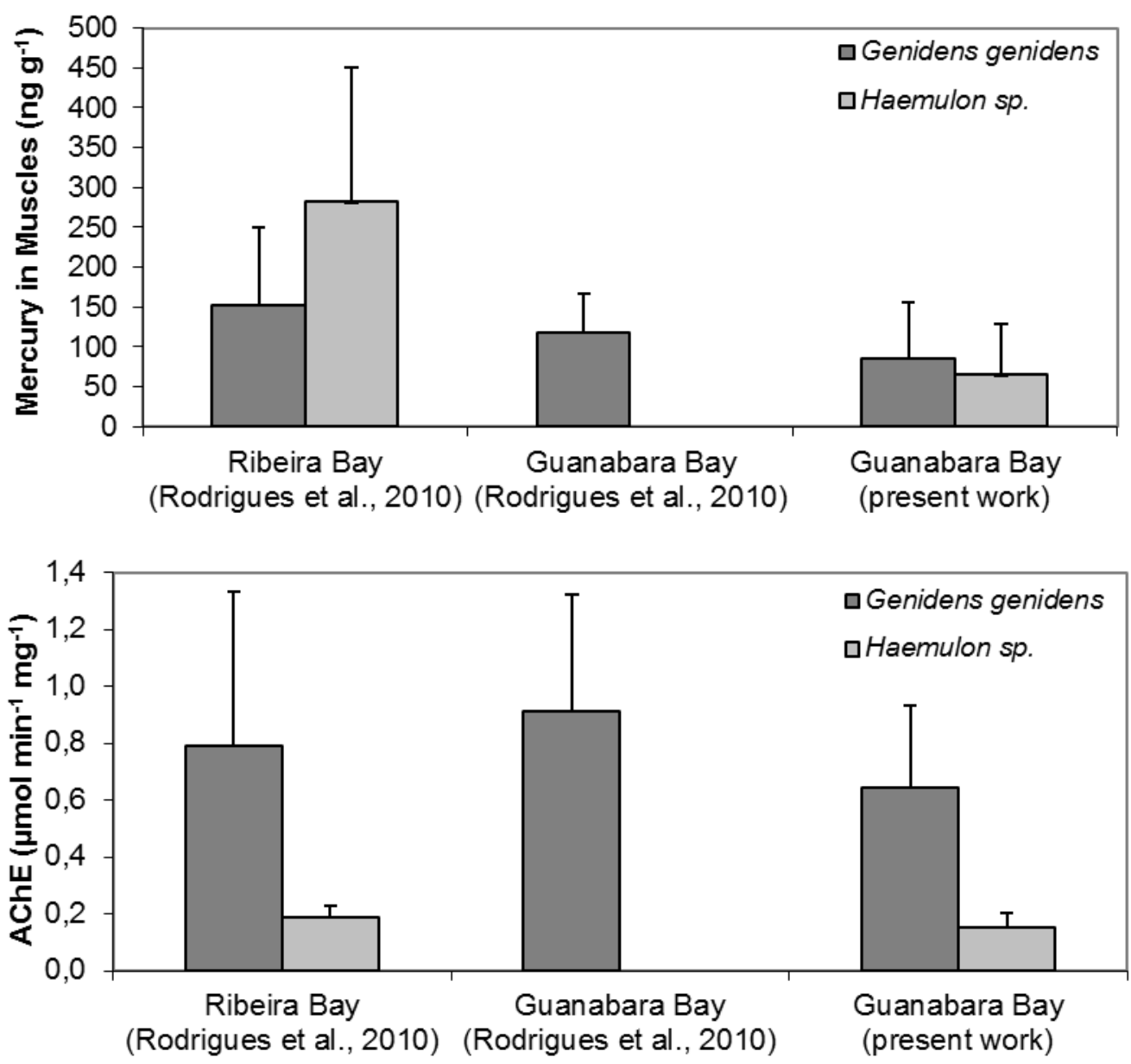

Figure 2. Total mercury concentrations $(\mathrm{Hg})$ in muscles (wet weight) and acetylcholinesterase activity (AChE) in two fish species from Guanabara and Ribeira bays. *significant differences $(\mathrm{p}<0.05)$

No significant correlation was found between mercury concentrations in muscles and AChE activity (Spearman correlation; $\mathrm{p}>0.05$ ), as well as no correlation of mercury concentrations in muscles with biometry either (Spearman correlation; p $>0.05$ ) (Figure 3). On the other hand, the AChE activity decreased with the fish growth (Spearman correlation; -0.56; $\mathrm{p}<0.05$ ) (Figure 3). Siscar and co-authors [37] have not found a clear relation or trend between AChE activity and ecological indicators. However, previously, Rodrigues et al. [21] found a negative correlation between $\mathrm{AChE}$ and mercury concentrations in muscles and in blood of G. genidens from Guanabara bay, which had suggested a possible inhibition scenario. In the present work, a negative correlation was found only between AChE activity in muscles and mercury concentrations in kidney of G. genidens (Spearman correlation; $-0.55 ; \mathrm{p}<0.05 ; \mathrm{n}=14$ ). Gill and co-workers [16] reported in laboratory conditions that AChE activity in brain, gills and liver decreased after exposure to mercury, but AChE activity in muscles was not altered.

Additionally, a reference area inside Guanabara bay could be chosen to compare the data with a supposed reference value, but among the three studied stations, none could be considered as unpolluted. This way, a comparison to previous data from a control area described by Rodrigues et al. [21] was carried out, with the only purpose of assisting the interpretation of AChE activity observed at Guanabara bay. Considering as reference these previous data from Ribeira bay (Figure 2), the AChE activities were similar ( $\mathrm{T}$ Student test; $\mathrm{t}$-value: $-0.95 ; \mathrm{p}=0.34$ ), although mercury concentrations were not ( $\mathrm{T}$ Student test; $\mathrm{t}$-value: $-2.11 ; \mathrm{p}<0.05$ ), being not possible to indicate $\mathrm{AChE}$ inhibition. 


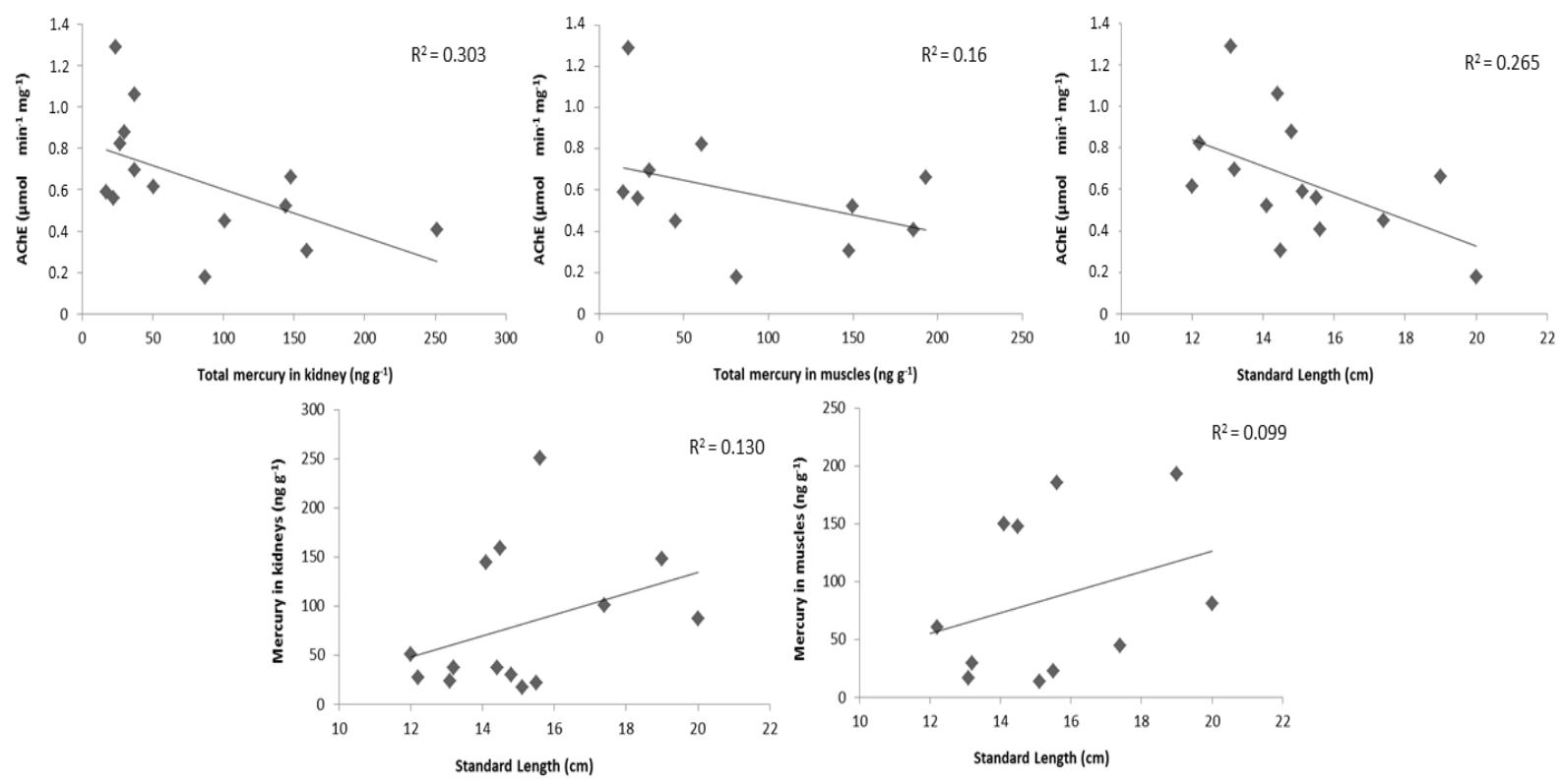

Figure 3. Linear regressions between total mercury concentrations in muscles and in kidneys (wet weight), standard length and acetylcholinesterase activity (AChE) in Genidens genidens from Guanabara bay-RJ.

For Haemulon sp. the enzyme activity showed a smaller range (0.06 to $0.22 \mu \mathrm{mol} \mathrm{min}{ }^{-1} \mathrm{mg}^{-1}$ protein). This natural difference between species (Mann-Whitney U test; Z: 4.44; $\mathrm{p}<0.001$ ) reflects different metabolisms, food habits and others biological factors. High AChE activities were described for 10 specimens of Haemulon steindachneri (Jordan \& Gilbert, 1882) from Ribeira bay $\left(0.76 \pm 0.25 \mu \mathrm{mol} \mathrm{min}^{-}\right.$ ${ }^{1} \mathrm{mg}^{-1}$ protein) (Rodrigues et al., 2010). Also for H. steindachneri, Oliveira and coworkers [38] described an AChE activity of $443 \mathrm{U} \mathrm{g} \mathrm{g}^{-1}$ in brains of $22 \mathrm{~cm}$ specimens.

At the present study, a negative linear tendency was found between mercury concentrations in muscles and AChE activity (Figure 4), suggesting a decrease on enzymatic response in specimens with higher mercury bioaccumulation. This indication is fortified, if we use the AChE activity found on the previous work at Ribeira bay as reference (Figure 2). AChE activity is lower at Guanabara bay than the adopted reference value ( $T$ Student test; t-value: $-2.66 ; \mathrm{p}<0.05$ ), as well as mercury concentrations in muscles, that were four times higher in the specimens from Guanabara bay (T Student test; t-value: 4.90; $\mathrm{p}<0.001)$. In other words, this species presented an opposite trend of mercury bioaccumulation and of the AChE response, compared to catfishes (Figures 2 and 3).
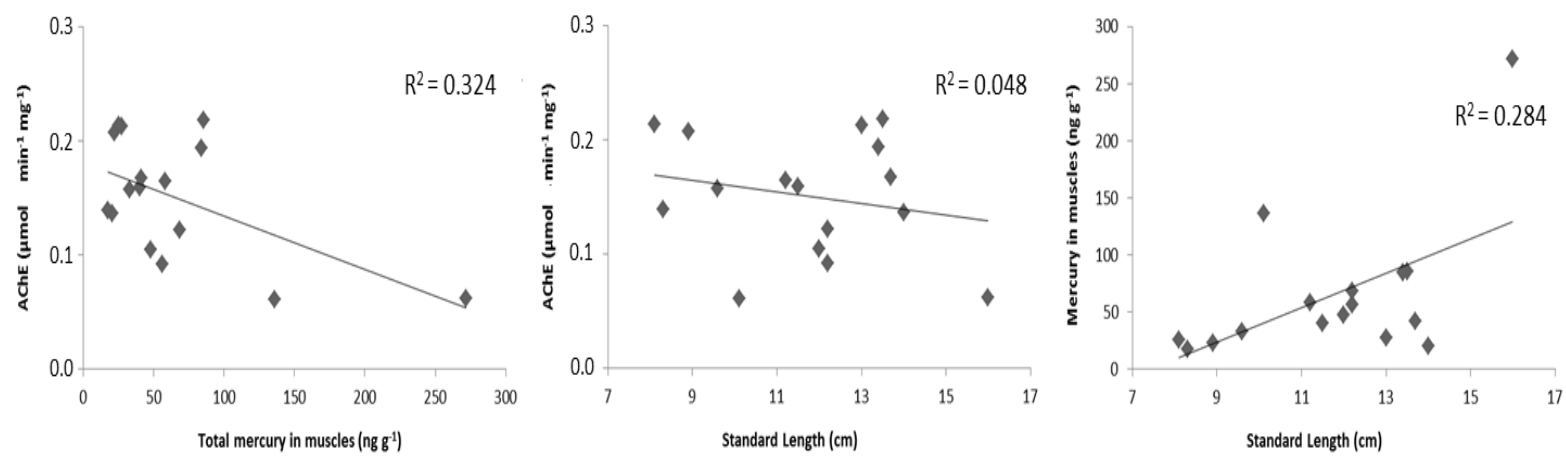

Figure 4. Linear regressions between total mercury concentrations in muscles (wet weight), standard length and acetylcholinesterase activity (AChE) in Haemulon sp. from Guanabara bay-RJ.

Besides ecological factors that could explain how the two fish species had different responses for the studied biomarkers, biochemical factors may also be considered. Differences on the AChE sensibility to 
toxic substances exposure were observed for fish species and invertebrates [39] and they could be linked to the active site of the enzyme that binds to alkyl chains of the substrates, such as acetylcholine iodide (AcSCh) and butyrylthiocholine iodide (BSCh).

Bioassays [10], [12], [13], [19], [22] and field works [18] [21] have suggested the mercury capacity of inhibit AChE activity. However, other studies found no inhibition indications [40]. AChE response to mercury exposure seems to vary not only according to fish species, but also considering the evaluated tissue and time of exposure. Newborn rats exposed to mercury had AChE activity inhibition in cerebellum and also an antagonistic relationship between mercury and zinc was observed, where newborn rats treated with zinc before mercury exposure did not presented AChE inhibition [20]. Richetti et al. [22] performed a bioassay using the fish species Danio rerio exposing the test group to mercury chloride II and $\mathrm{Pb}\left(\mathrm{CH}_{3} \mathrm{COO}\right)_{2}$ and observed AChE inhibition after 24 hours. However, after 30 days of exposure, the acetylcholine hydrolysis came back to normal.

Nevertheless, it is important to consider that other pollutants may be influencing on AChE response, such as $\mathrm{Cu}$ or organic substances, since Guanabara bay receives different types of effluents containing several chemical substances. Tilapia exposed to reuse waters (product of sewage treatment) presented AChE inhibition in liver [41]. For copper $(\mathrm{Cu})$ exposure, the inhibition has been already indicated for vertebrate and invertebrate species [5], [6], [7], [8], [9], [11]. Vieira et al. [10] observed inhibition for the fish species Pomatoschistus micros exposed to sub-lethal concentrations of $\mathrm{Cu}$ and $\mathrm{Hg}$, inducing also oxidative stress, peroxidation of lipids and increase of energy production by anaerobiosis. Shukor et al [13] observed inhibition of enzymatic activity in the fish species Electrophorus electricus as result of an exposure to $5 \mathrm{mg} \mathrm{L}^{-1}$ of $\mathrm{Cu}, \mathrm{Ag}$ and $\mathrm{Hg}$, separately. In Lima et al. [12], AChE inhibition was only observed for Danio rerio exposed to higher concentrations than $10 \mathrm{mM}$ of $\mathrm{Cd}, \mathrm{Cu}, \mathrm{Pb}$ and Fe, separately. Roy et al. [15] suggested that arsenic had a strong action on acetylcholinesterase activity in brains.

\section{Conclusion}

It was observed that AChE activity is decreased at Guanabara bay for both species, although Haemulon sp. seemed to be more susceptible / sensible, presenting a clear indication of AChE inhibition. Despite the correlations between AChE activity and mercury concentrations, it is important to highlight that AChE results could reflect the exposure to a mix of pollutants, including mercury, at Guanabara bay. The possible decrease of AChE activity observed for the last years at Guanabara bay must be completely understood, in order to delimit the actual scenario of pollutants exposure and the respective biological responses.

Acknowledgments. The authors would like to thank to CAPES (Coordination for the Improvement of Higher Level -or Education- Personnel) and the National Institute for Science and Technology (INCTTMCOcean; CNPq/573-601/2008-9) for the financial supports.

\section{References}

1. M.B Moretto, C.L. Lermen, V.M. Morsch, D. Bohrer, R.F. Ineu, A.C. Da Silva, D. Balz, M.R.C. Schetinger, "Effect of subchronic treatment with mercury chloride on NTPDase, 5'-nucleotidase and acetylcholinesterase from cerebral cortex of rats", Journal of Trace Elements on Medicine Biology, vol 17, no 4, pp. 255-260, 2004.

2. R. Lavado, R. Ureña, R. Martin-Skilton, A. Torreblanca, J. Del Ramo, D. Raldúa, C. Porte, "The combined use of chemical and biochemical markers to assess water quality along the Ebro River Ramo". Environmental Pollution, vol 139, pp. 330-339, 2006.

3. A.T.B. GUIMARÃES, H.C. SILVA DE ASSIS, and W. BOEGER, "The effect of trichlorfon on acetylcholinesterase activity and histopathology of cultivated fish Oreochromis niloticus". Ecotoxicology and Environmental Safety, vol 68, pp. 57-62, 2007.

4. M.B. Fonseca, L. Glusczak, B.S. Moraes, C.C. Menezes, A. Pretto, M.A. Tierno, R. Zanella, F.F. Gonçalves, V.L. Loro, "The 2,4-D herbicide effects on acetylcholinesterase activity and metabolic parameters of piava freshwater fish (Leporinus obtusidens)". Ecotoxicology Environmental Safety, vol 69, pp. 416-420, 2008. 
5. M.F. Frasco, D. Fournier, F. Carvalho, L. Guilhermino, "Do metals inhibit acetylcholinesterase (AChE)? Implementation of assay conditions for the use of AChE activity as a biomarker of metal toxicity", Biomarkers, vol 10, pp. 360-75, 2005.

6. M.F. Frasco, J.P. Colletier, M. Weik, F. Carvalho, L. Guilhermino, J. Stojan, D. Fournier, "Mechanisms of cholinesterase inhibition by inorganic mercury". FEBSJ, vol 274, pp. 1849-61, 2007.

7. M.F. Frasco, D. Fournier, F. Carvalho, L. Guilhermino, "Does mercury interact with the inhibitory effect of dichlorvos on Palaemon serratus (Crustacea: Decapoda) cholinesterase?" Science of the Total Environment, vol 404, pp. $88-93,2008$.

8. L. Pari and P. Murugavel, "Diallyl tetrasulfide improves cadmium induced alterations of acetylcholinesterase, ATPases and oxidative stress in brain of rats", Toxicology, vol 234, pp. 44-50, 2007.

9. G. Petraglio, M. Bartolini, D. Branduardi, V. Andrisano, M. Recanatini, F.L. Gervasio, A. Cavalli, M. Parrinello, "The role of $\mathrm{Li}^{+}, \mathrm{Na}^{+}$, and $\mathrm{K}^{+}$in the ligand binding inside the human acetylcholinesterase gorge". Proteins, vol 70, pp. 779-785, 2008.

10. L.R. Vieira, C. Gravato, A.M. Soares, F. Morgado, L. Guilhermino, "Acute effects of copper and mercury on the estuarine fish Pomatoschistus microps: linking biomarkers to behavior", Chemosphere, vol 76, no 10, pp. 1416-27, 2009.

11. F.A. Tilton, T.K. Bammler, and E.P. Gallagher, "Swimming impairment and acetylcholinesterase inhibition in zebrafish exposed to copper or chlorpyrifos separately, or as mixtures", Comparative Biochemistry and Physiology, Part C, vol 153, pp. 9-16, 2011.

12. D. Lima, G.M. Roque, E.A. Almeida, "In vitro and in vivo inhibition of acetylcholinesterase and carboxylesterase by metals in zebrafish (Danio rerio)", Marine Environmental Research, vol 91, pp. 45-51, 2013.

13. M.Y. Shukor, L.G. Tham, M.I. Halmi, I. Khalid, G. Begum, M.A. Syed, "Development of an inhibitive assay using commercial Electrophorus electricus acetylcholinesterase for heavy metal detection". Journal of Environmental Bioogy, vol 34, no 5, pp. 967-970, 2013.

14. J.F. Gonçalves, A.M. Fiorenza, R.M. Spanevello, C.M. Mazzanti, G.V. Bochi, F.G. Antes, N. Stefanello, M.A. Rubin, V.L. Dressler, V.M. Morsch, M.R.C. Schetinger, "N-acetylcysteine prevents memory deficits, the decrease in acetylcholinesterase activity and oxidative stress in rats exposed to cadmium", Chemico-Biological Interactions, vol 186, pp. 53-60, 2010.

15. S. Roy, A. Chattoraj, S. Bhattacharya, "Arsenic-induced changes in optic tectal histoarchitecture and acetylcholinesterase-acetylcholine profile in Channa punctatus: Amelioration by selenium", Comparative Biochemistry and Physiology, Part C, vol 144, pp. 16-24, 2006.

16. T. Gill, "Use of the fish enzyme system in monitoring water quality: effects of mercury on tissue enzymes", Comparative Biochemistry and Physiology, Part C, vol 97, no 2, pp. 287-292, 1990.

17. WHO. Environmental Health Criteria (EHC 101). Methylmercury. Geneva, 143p. 1990.

18. B.P. Shaw and A.K. Panigrahi, "Brain AChE activity studies in some fish species collected from a mercury contaminated estuary". Water Air Soil Pollution, vol 53, pp. 327-334, 1990.

19. A. Suresh, B. Sivaramakrishna, P.C. Victoriamma, K. Radhakrishnaiah, "Comparative study on the inhibition of acetylcholinesterase activity in the freshwater fish Cyprinus carpio by mercury and zinc". Biochem. Int., vol 26, pp. 367-375, 1992.

20. F.R. Franciscato, N.M. Goulart, F.A. Lovatto, E.M.M Duarte, V.L. Flores, N.C. Dressler, M.E. Peixoto, C. Pereira, " $\mathrm{ZnCl}_{2}$ exposure protects against behavioral and acetylcholinesterase changes induced by $\mathrm{HgCl}_{2}$ ", Int. J. Devl Neuroscience, vol 27, pp. 459-468, 2009.

21. A.P.C. Rodrigues, P.O. Maciel, L.C.C. Pereira da Silva, C. Albuquerque, A.F. Inácio, M. Freire, A.R. Linde, N.R.P. Almosny, J.V. Andreata, E.D. Bidone, Z.C. Castilhos, "Biomarkers for mercury exposure in tropical estuarine fish", Journal of Brazilian Society of Ecotoxicology, vol 5, no 1, pp. 9-18, 2010.

22. S.K. Richetti, D.B. Rosemberg, J. Ventura-Lima, J.M. Monserrat, M.R. Bogo, C.D. Bonan, "Acetylcholinesterase activity and antioxidant capacity of zebrafish brain is altered by heavy metal exposure", NeuroToxicology, vol 32, pp. 116-122, 2011.

23. T.B. Jesus, P.G.A. Almeida, C.S. Vergílio, A.L.S. Machado, C.E.V. Carvalho, "Acute intraperitoneal mercury chloride contamination and distribution in liver, muscle and gill of a neotropical fish Hoplias malabaricus (BLOCK, 1794)", Brazilian Archieve of Biology Technology, vol 54, pp. 379-386, 2011. 
24. T.B. Jesus, J.S. Colombi, C.A.O. Ribeiro, H.C.S. de Assis, C.E.V. de Carvalho, "Cholinestarase activity in methylmercury and mercury chloride exposure fish", Ecotoxicology Environmental Contamination, vol 8, pp. 147$148,2013$.

25. J.R.M.A. Costa, M. Mela, H.C.S. Assis, E. Pelletier, M.A.F. Randia, C.A. Oliveira Ribeiro, "Enzymatic inhibition and morphological changes in Hoplias malabaricus from dietary exposure to lead (II) or methylmercury". Ecotoxicology and Environmental Safety, vol 67, pp. 82-88, 2007.

26. W. Machado, R.E. Santelli, D.D. Loureiro, E.P. Oliveira, A.C. Borges, V.K. Ma, L.D. Lacerda, "Mercury accumulation in sediments along an eutrophication gradient in Guanabara bay, Southeast Brazil", Journal of Brazilian Chemistry Society, vol 19, no 3, pp. 569-575, 2008.

27. A.P.C. Rodrigues, P.O. Maciel, L.C.C. Pereira da Silva, N.R.P. Almosny, J.V. Andreata, E.D. Bidone, Z.C. Castilhos, "Relationship between mercury concentrations in the blood with that in the muscle of four estuarine tropical fish species, Rio de Janeiro State, Brazil", Bulletin of Environmental Contamination and Toxicology, vol 86, pp. 357-362, 2011.

28. H.A. Kehrig, T.G. Seixas, E.A. Palermo, A.P. Baêta, C.W. Castelo-Branco, O. Malm, I. Moreira, "The relationships between mercury and selenium in plankton and fish from a tropical food web". Environmental Science and Pollution Research, vol 16, pp. 10-24, 2009.

29. A. Carvalho-Filho, Peixes: Costa Brasileira. São Paulo: Melro, 1999. 320p.

30. P.T.C. Chaves and A.L. Vendel, "Aspectos da alimentação de Genidens genidens (Valenciennes) (Siluriformes, Ariidae) na Baía de Guaratuba, Paraná”, Revista Brasileira de Zoologia, vol 13, no 3, pp. 669-675, 1996.

31. J.S. Nelson, Fishes of the world. Wiley, New York. 1994.

32. A.D. Eaton, A.E. Greenberg, and L.S. Clesceri, "10600: Fish. In: Standard Methods for the examination of water and wastewater". Washington D. C.: APHA, pp.1092-1107, 1998.

33. J.J. Oliveira-Silva, S.R. Alves, A.F. Inácio, A. Meyer, P.N. Sarcinelli, M.F. Ferreira, J.C. Cunha, J.C. Moreira, "Cholinesterase activities determination in frozen blood samples: An improvement to the occupational monitoring in developing countries", Hum. Exp. Toxicol., vol 19, no 3, pp. 173-177, 2000.

34. G.L. Elmann, K. Courtney, J.R.A. Andres, R. Featherstone, "A new and rapid colorimetric determination of acetylcholinesterase activity", Biochem. Pharmacol, vol 7, pp. 89-95, 1961.

35. J.B. Cunha, J.S. Lima, M.V.C. Faria, "Brain acetylcholinesterase as an in vitro detector of organophosphorus and carbamate insecticides in water", Water Research, vol 25, no 7, pp. 835-840, 1991.

36. J.S. Azevedo, E.S. Braga, H.C. Silva de Assis, C.A. Oliveira Ribeiro, "Biochemical changes in the liver and gill of Cathorops spixii collected seasonally in two Brazilian estuaries under varying influences of anthropogenic activities", Ecotoxicology and Environmental Safety, vol 96, pp. 220-230, 2013.

37. R. Siscar, S. Koenig, A. Torreblanca, M. Solé, "The role of metallothionein and selenium in metal detoxification in the liver of deep-sea fish from the NW Mediterranean Sea", Science of the Total Environment, vol 466-467, pp. 898-905, 2014.

38. M.M. Oliveira, M.V. Silva Filho, V.L.F.C. Bastos, F.C. Fernandes, J.C. Bastos, "Brain acetylcholinesterase as a marine pesticide biomarker using Brazilian fishes", Marine Environmental Research, vol 63, pp. 303-312, 2007.

39. J.M. Monserrat, P.E. Martínez, L.A. Geracitano, L.L. Amado, C.M.G. Martins, G.L.L. Pinho, I.S. Chaves, M. Ferreira-Cravo, J. Ventura-Lima, A. Bianchini, "Pollution biomarkers in estuarine animals: Critical review and new perspectives", Comparative Biochemistry and Physiology, vol 146, pp. 221-234, 2007.

40. M.A. Grippo and A.G. Heath, "The effect of mercury on the feeding behavior of fathead minnows (Pimephales promelas)", Ecotoxicology and Environmental Safety, vol 55, pp. 187-198, 2003.

41. S.M. Al-Ghais, "Acetylcholinesterase, glutathione and hepatosomatic index as potential biomarkers of sewage pollution and depuration in fish", Marine Pollution Bulletin, vol 74, pp. 183-186, 2013. 